\title{
Wpływ wymuszeń mechanicznych na zmianę właściwości tribologicznych smarów plastycznych wytworzonych na bazie mineralnej
}

W publikacji przedstawiono wyniki badania wpływu wymuszeń mechanicznych na właściwości tribologiczne smarów plastycznych wytworzonych na bazie oleju mineralnego z zagęszczaczem nieorganicznym Aerosil ${ }^{\circledR}$. Wykonano testy tribologiczne za pomocą aparatu czterokulowego dla badanych smarów plastycznych poddanych wymuszeniom mechanicznym $(60,250,500,1000,3000,5000$ oraz 10000 powtórzeń), a ich rezultaty porównano z wynikami badań tribologicznych dla smaru, który nie podlegał wymuszeniom mechanicznym. Do oceny właściwości tribologicznych wykorzystano wyniki badań granicznego obciążenia zużycia, obciążenia zespawania, obciążenia zacierającego, granicznego obciążenia zatarcia oraz granicznego nacisku zatarcia. Na podstawie wyników ww. badań tribologicznych stwierdzono, że wymuszenia mechaniczne, którym poddano badane smary plastyczne, wpłynęły na zmianę podstawowych parametrów tribologicznych. Poprawę właściwości smarnych mineralnych smarów plastycznych uzyskiwano do momentu, w którym smar był poddawany wymuszeniom mechanicznym w liczbie 500 powtórzeń. Im większe wymuszenia mechaniczne, tym coraz słabsze właściwości smarne badanych smarów plastycznych, jednakże spadek wartości badanych parametrów tribologicznych dla mineralnych smarów plastycznych, wywołany wymuszeniami mechanicznymi, nie dyskwalifikuje ich z zastosowania praktycznego.

Słowa kluczowe: smar plastyczny, właściwości przeciwzużyciowe, właściwości przeciwzatarciowe, olej parafinowy, krzemionka amorficzna, aparat czterokulowy, wymuszenia mechaniczne.

\section{The influence of mechanical forces on the change of the tribological properties of mineral- based lubricating greases}

The publication presents the results of investigations of the influence of mechanical forces on the tribological properties of greases produced on mineral-based oil with an inorganic thickener Aerosil ${ }^{\circledR}$. Investigation of tribological properties were carried out with the four ball apparatus for lubricating greases made on mineral-based oil subjected to mechanical forces $(60 \mathrm{x}, 250 \mathrm{x}, 500 \mathrm{x}, 1000 \mathrm{x}, 3000 \mathrm{x}, 5000 \mathrm{x}$ and $10000 \mathrm{x})$ and the obtained results were compared with the results of tribological research for lubricating grease, which wasn't subjected to the mechanical forces. For estimation of the tribological properties the results of investigations concerning, limiting load of wear, weld point, scuffing load, limiting load of scuffing and limiting pressure of seizure were used. On the basis of the above mentioned results of tribological investigations of lubricating compositions, it was ascertained that the mechanical forces under which the researched lubricating greases were subjected, brought about a change in the basic tribological parameters. Improvement of lubricating properties of mineral lubricating greases was obtained until the moment at which the grease was kneaded 500-times. The greater the mechanical forces, the weaker the lubricating properties of the researched lubricating greases, however the decline of the value of the researched tribological parameters for mineral lubricating greases caused by mechanical forces doesn't disqualify them for practical application.

Key words: lubricating grease, antiwear properties, antiscuffing properties, paraffin oil, amorphous silica, four-ball machine, mechanical forces. 


\section{Wprowadzenie}

Różnorodność maszyn i urządzeń sprawia, że istnieje potrzeba spełnienia wymagań dotyczących jakości stosowanych środków smarowych - szczególnie wtedy, gdy dochodzi do kontaktu smaru z żywnością czy organizmami żywymi. Smary plastyczne przeznaczone dla przemysłu spożywczego powinny wykazywać ekologiczny charakter, który oparty jest na znacznym ograniczeniu zawartości toksycznych substancji chemicznych, ponieważ produkty te muszą być obojętne fizjologicznie i charakteryzować się wysoką biodegradowalnością. Wytworzenie środków smarowych o odpowiednich właściwościach wymaga zastosowania baz olejowych, które zapewnią produktowi końcowemu takie cechy, aby nie stwarzał on zagrożenia dla środowiska naturalnego. Postanowiono zastosować olej mineralny o czystości farmaceutycznej, mimo niewysokiej biodegradowalności, ze względu na bardzo dobre właściwości lepkościowo-temperaturowe oraz smarne, które warunkują jego przydatność do smarów plastycznych stosowanych w przemyśle spożywczym $[3,4,8,9,14,10]$. Rozwój technologii implikuje opracowywanie i stosowanie smarów plastycznych spełniających coraz wyższe oczekiwania w zakresie właściwości ekologicznych, tribologicznych i eksploatacyjnych.

Warunki eksploatacji wymuszają stosowanie smarów plastycznych o ściśle określonych właściwościach użytkowych. Zmiana struktury smaru plastycznego poddanego obciążeniom mechanicznym skutkuje pogorszeniem parametrów eksploatacyjnych środka smarowego i skróceniem czasu jego pracy, co w konsekwencji prowadzi do konieczności wymiany smaru na nowy. $\mathrm{O}$ zmianach struktury smaru plastycznego świadczą wyniki badań odporności środka smarowego na wymuszenia mechaniczne oraz zmiana właściwości smarnych smaru plastycznego poddanego wymuszeniom mechanicznym $[5,12,17,19,20]$.

W czasie eksploatacji musi być spełniany odpowiedni poziom właściwości smarnych, dlatego za celowe uznano zbadanie poziomu właściwości smarnych środków smarowych po wymuszeniach mechanicznych na przykładzie potencjalnie biodegradowalnych smarów plastycznych wytworzonych na bazie mineralnej.

Jako fazę dyspergującą zastosowano głęboko oczyszczony mineralny olej biały o czystości farmaceutycznej
Finavestan A360B, spełniający wymagania czystości według FDA 21 CFR 172-878, farmakopei europejskiej i USA oraz dyrektywy 2002/72/EC. Olej mineralny A360B nie zawiera siarki i aromatycznych węglowodorów, jest bezbarwny, bez zapachu, jego lepkość w temperaturze $40^{\circ} \mathrm{C}$ wynosi $70 \mathrm{~mm}^{2} / \mathrm{s}$, temperatura płynięcia to $18^{\circ} \mathrm{C}$, temperatura zapłonu $250^{\circ} \mathrm{C}$, a gęstość w $15^{\circ} \mathrm{C}-870 \mathrm{~kg} / \mathrm{m}^{3}$. Olej ten ma zastosowanie jako plastyfikator przy wytwarzaniu polistyrenu i jako wypełniacz do elastomerów termoplastycznych. Jest stosowany w przemyśle kosmetycznym i farmaceutycznym jako dodatek przeciwpienny, film ochronny i środek do uwalniania z form w przemyśle spożywczym, a także jako środek smarowy chroniący elementy maszyn spożywczych przed zużywaniem i zatarciem oraz jako baza olejowa smarów plastycznych [12].

Jako fazę zdyspergowaną badanych kompozycji smarowych zastosowano hydrofilową krzemionkę koloidalną - czyli ditlenek krzemu o wymiarach cząstek $7 \div 40 \mathrm{~nm}$, tworzący rozbudowane struktury przestrzenne, w których każdy atom krzemu jest połączony z czterema atomami tlenu, a każdy atom tlenu łączy się z dwoma atomami krzemu. Powierzchnia krzemionki zawiera także atomy wodoru i grupy hydroksylowe. Polarny charakter sprawia, że łatwo wiąże się z cząsteczkami olejów dzięki siłom van der Waalsa. Modyfikacja krzemionki dimetylodichlorosilanem znacznie zmniejsza zjawisko aglomeracji ziaren krzemionki, pozwalając na łatwiejsze i bardziej skuteczne wbudowanie cząsteczek w strukturę smaru plastycznego, nawet przy łagodnych warunkach mieszania. Jest ona substancją o wysokiej temperaturze topnienia i wrzenia oraz charakteryzuje się niezwykłą odpornością chemiczną, ponadto jest nietoksyczna, co jest niezwykle ważne przy komponowaniu środków smarowych. Stosuje się ją jako doskonały środek zagęszczający oraz antysedymentacyjny. Poprawa parametrów tribologicznych przypisywana jest dużej powierzchni właściwej oraz bardzo dobrym oddziaływaniom na granicy faz $[1,2,11,18]$.

Celem pracy było zbadanie wpływu wymuszeń mechanicznych na zmianę właściwości tribologicznych smarów plastycznych wytworzonych na bazie oleju mineralnego, przeznaczonych dla przemysłu spożywczego, opracowanych w Instytucie Technologii Eksploatacji - PIB w Radomiu.

\section{Część doświadczalna}

\section{Charakterystyka obiektów badań}

Do badań wykorzystano smary plastyczne opracowane z zastosowaniem nietoksycznych składników stanowiących fazę dyspergującą i zdyspergowaną. Substancję stanowiącą fazę dyspergującą wybrano z grupy olejów mineralnych. Wytypowano olej o najlepszych właściwościach tribologicznych oraz fizykochemicznych, a mianowicie parafinę o czystości farmaceutycznej. Jako fazę zdyspergowaną zastosowano 
modyfikowaną krzemionkę w postaci Aerosilu ${ }^{\circledR}$. Wykorzystując wybrane składniki, wytworzono smary mieszczące się w drugiej klasie konsystencji i mające zastosowanie w przemyśle spożywczym.

Przyjęto następujące oznaczenia wytworzonych kompozycji smarowych: olej parafinowy z zagęszczaczem w postaci modyfikowanej krzemionki Aerosil ${ }^{\circledR}$ (smar A), olej parafinowy z zagęszczaczem w postaci modyfikowanej krzemionki Aerosi $l^{\circledR}$ poddany wymuszeniom mechanicznym w liczbie 60 powtórzeń (smar A1), olej parafinowy z zagęszczaczem $\mathrm{w}$ postaci modyfikowanej krzemionki Aerosil ${ }^{\circledR}$ poddany wymuszeniom mechanicznym w liczbie 250 powtórzeń (smar A2), olej parafinowy z zagęszczaczem w postaci modyfikowanej krzemionki Aerosil ${ }^{\circledR}$ poddany wymuszeniom mechanicznym w liczbie 500 powtórzeń (smar A3), olej parafinowy z zagęszczaczem w postaci modyfikowanej krzemionki Aerosil ${ }^{\circledR}$ poddany wymuszeniom mechanicznym w liczbie 1000 powtórzeń (smar A4), olej parafinowy z zagęszczaczem w postaci modyfikowanej krzemionki Aerosil ${ }^{\circledR}$ poddany wymuszeniom mechanicznym w liczbie 3000 powtórzeń (smar A5), olej parafinowy z zagęszczaczem w postaci modyfikowanej krzemionki Aerosil ${ }^{\mathbb{B}}$ poddany wymuszeniom mechanicznym w liczbie 5000 powtórzeń (smar A6) oraz olej parafinowy z zagęszczaczem w postaci modyfikowanej krzemionki Aerosil ${ }^{\circledR}$ poddany wymuszeniom mechanicznym w liczbie 10000 powtórzeń (smar A7). Do struktury każdego smaru plastycznego wprowadzono zagęszczacz w ilości $8 \% \mathrm{~m} / \mathrm{m}$. Tak wytworzone kompozycje smarowe oznaczono następnie symbolami: A, A1, A2, A3, A4, A5, A6 i A7. Wyniki badań penetracji oraz temperatury kroplenia poddanych analizie kompozycji smarowych przedstawiono $\mathrm{w}$ tablicy 1 .

Tablica 1 . Wyniki badań penetracji oraz temperatury kroplenia analizowanych kompozycji smarowych

\begin{tabular}{|c|c|c|c|}
\hline $\begin{array}{c}\text { Badany } \\
\text { smar }\end{array}$ & $\begin{array}{c}\text { Penetracja } P \\
{[\mathrm{~mm} / 10]}\end{array}$ & $\begin{array}{c}\text { Temperatura } \\
\text { kroplenia } T_{k} \\
{\left[{ }^{\circ} \mathrm{C}\right]}\end{array}$ & $\begin{array}{c}\text { Wymuszenia } \\
\text { mechaniczne } \\
\text { (ilość ruchów tłoka } \\
\text { podczas ugniatania } \\
\text { badanych próbek) }\end{array}$ \\
\hline A & 269,50 & 195,0 & 0 \\
\hline A1 & 279,00 & 198,5 & 60 \\
\hline A2 & 297,75 & 202,0 & 250 \\
\hline A3 & 316,50 & 206,5 & 500 \\
\hline A4 & 339,00 & 209,5 & 1000 \\
\hline A5 & 365,25 & 211,0 & 3000 \\
\hline A6 & 378,75 & 213,5 & 5000 \\
\hline A7 & 401,25 & 215,5 & 10000 \\
\hline
\end{tabular}

\section{Badania właściwości tribologicznych}

\section{Aparatura}

Do wyznaczenia właściwości tribologicznych badanych kompozycji smarowych wykorzystano aparat czterokulowy T-02 [6, 7, 21]. W celu określenia wymiarów śladu zużycia powierzchni kulek testowych zastosowano mikroskop optyczny Nikon MM-40 [21]. Uzyskane wyniki posłużyły do ustalenia wartości $\mathrm{G}_{\mathrm{oz} / 40}$ oraz $p_{o z}$, czyli oceny właściwości przeciwzużyciowych i przeciwzatarciowych smarów plastycznych poddanych badaniom tribologicznym $[15,16]$.

Wymuszenia mechaniczne, którym podlegały badane smary plastyczne, były realizowane za pomocą aparatu do ugniatania smarów produkcji Instytutu Technologii Eksploatacji - PIB. W trakcie realizacji prac ustalono, że smary będą poddane wymuszeniom mechanicznym w liczbie 60 , $250,500,1000,3000,5000$ i 10000 powtórzeń, aby dostrzec moment, w którym właściwości smarne badanych kompozycji ulegają obniżeniu.

\section{Sposób prowadzenia badań}

Właściwości smarne badanych kompozycji zostały określone poprzez pomiar granicznego obciążenia zużycia $\left(G_{o z / 40}\right)$, obciążenia zespawania $\left(P_{z}\right)$, obciążenia zacierającego $\left(P_{t}\right)$, granicznego obciążenia zatarcia $\left(P_{o z}\right)$ oraz granicznego na- cisku zatarcia $\left(p_{o z}\right)$ na aparacie czterokulowym. Elementami testowymi były kulki o średnicy $12,7 \mathrm{~mm}$, wykonane ze stali łożyskowej ŁH 15 , chropowatości powierzchni $R a=0,32 \mu \mathrm{m}$ i twardości $60 \div 65$ HRC. Pomiar granicznego obciążenia zużycia $\left(G_{o z / 40}\right)$ wykonano przy obciążeniu węzła tarcia siłą $392,4 \mathrm{~N}$ przez cały czas trwania testu $-3600 \mathrm{~s}$ oraz przy prędkości obrotowej kulki wynoszącej 500 obr./min, zgodnie z warunkami testu przewidzianymi w WTWT-94/ MPS-025 [23]. Pomiar obciążenia zespawania przeprowadzono zgodnie z normą PN-76/C-04147. Oznaczenie to polegało na przeprowadzeniu 10-sekundowych biegów zespołu czterech kulek w obecności środka smarowego pod coraz większym obciążeniem, aż do zespawania kulek. Natomiast pomiar właściwości smarnych w warunkach zacierania (tj. pod ciągle wzrastającym obciążeniem w czasie biegu badawczego) wykonano zgodnie z metodyką opracowaną przez Instytut Technologii Eksploatacji - PIB. Badanie przeprowadzono przy liniowo wzrastającym obciążeniu od 0 do $7200 \mathrm{~N}$ w czasie $18 \mathrm{~s}$, przy prędkości obrotowej wrzeciona $500 \mathrm{obr}$./min i prędkości narastania obciążenia 409 N/s. Gdy następuje nagły wzrost momentu tarcia, to poziom obciążenia węzła określany jest jako obciążenie zacierające $P_{t}$. Pomiar prowadzono do chwili osiągnięcia granicznego 
momentu tarcia $10 \mathrm{Nm}$ lub maksymalnego obciążenia aparatu $7200 \mathrm{~N}$. Ten punkt określono jako graniczne obciążenie zatarcia $P_{o z}$. Za wynik końcowy przyjmowano średnią arytmetyczną z co najmniej trzech oznaczeń nieróżniących się od siebie więcej niż o 10\%. Do obróbki statystycznej wyników zastosowano test Q-Dixona przy poziomie ufności 95\%.

Graniczny nacisk zatarcia jest miarą właściwości przeciwzatarciowych środków smarowych w warunkach zacierania. Oznaczenie tego parametru polegało na wyliczeniu jego wartości zgodnie ze wzorem: $p_{o z}=0,52 \times P_{o z} / d_{o z}^{2}$, gdzie $P_{o z}-$ graniczne obciążenie zatarcia, a $d_{o z}$ - średnica skazy powstałej na kulkach stalowych użytych do badania $[6,7,15,16,21,22]$.

Niepewność wyznaczenia badanych wielkości (granicznego obciążenia zużycia $G_{o z / 40}$, obciążenia zespawania $P_{z}$, obciążenia zacierającego $P_{t}$, granicznego obciążenia zatarcia $P_{o z}$ oraz granicznego nacisku zatarcia $p_{o z}$ ) oszacowano na podstawie klasy dokładności zastosowanej aparatury pomiarowej. Przynależność poszczególnych wyników badanych wielkości, tj. $G_{o z / 40}, P_{z}, P_{t}, P_{o z}$ i $p_{o z}$, do zbioru danych weryfikowano za pomocą testu Q-Dixona przy 95-procentowym poziomie ufności $[15,16]$.

\section{Omówienie wyników}

Poniżej przedstawiono wyniki badań tribologicznych (właściwości przeciwzatarciowych i przeciwzużyciowych) mineralnych smarów plastycznych poddanych wymuszeniom mechanicznym. Właściwości przeciwzużyciowe badanych kompozycji smarowych określono poprzez wyznaczenie granicznego obciążenia zużycia $G_{o z / 40}$ węzła tarcia. Uzyskane wyniki przedstawiono na rysunku 1 .

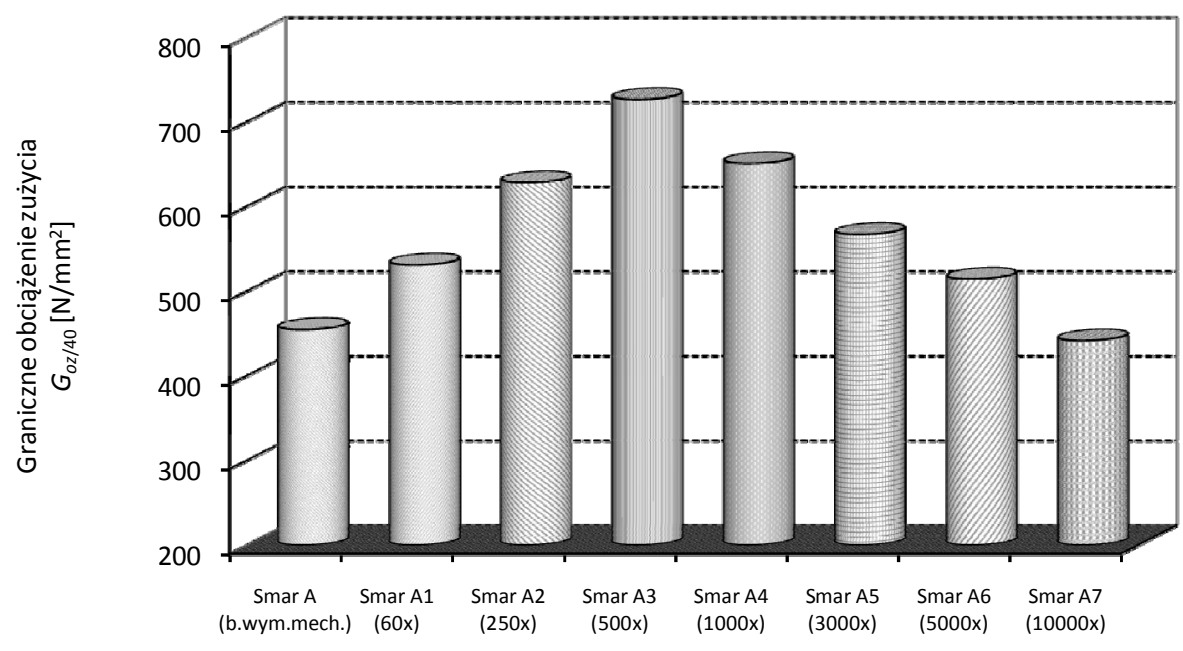

Rys. 1. Wpływ wymuszeń mechanicznych na zmianę granicznego obciążenia zużycia badanych smarów plastycznych

Graniczne obciążenie zużycia pozwala określić poziom właściwości przeciwzużyciowych smarów plastycznych biorących udział w eksperymencie. Na podstawie analizy wykonanych badań stwierdzono, że zastosowanie wymuszeń mechanicznych zmieniło zdolność smarów do przeciwzużyciowej ochrony węzła tarcia. Po wykonaniu badań dla każdego z wytworzonych smarów plastycznych stwierdzono mniejsze zużycie węzła tarcia dla kompozycji, które podlegały wymuszeniom mechanicznym w zakresie od 60 do 5000 powtórzeń, w stosunku do kompozycji podstawowej. Natomiast kompozycja poddana wymuszeniom w liczbie 10000 powtórzeń charakteryzowała się niższym poziomem właściwości przeciwzużyciowych. O trwałości warstwy granicznej świadczy wartość granicznego obciążenia zużycia $G_{o z / 40}$. Im wyższy wskaźnik, tym większa trwałość warstwy granicznej i zmniejszenie zużycia. Najkorzystniejszymi właściwościami przeciwzużyciowymi charakteryzuje się kompozycja A3, która podlegała wymuszeniom mechanicznym w liczbie 500 powtórzeń, natomiast kompozycja A7 (poddana wymuszeniom mechanicznym w liczbie 10000 powtórzeń) reprezentuje najniższą wartość parametru $G_{o z / 40}$. W kompozycjach smarów podlegających eksperymentowi zaobserwowano wzrost wartości parametru $G_{o z / 40}$, odpowiednio o $16,8 \%$ (smar A1 - ugniatany 60 razy), o $38,2 \%$ (smar A2 - ugniatany 250 razy) i o $59,8 \%$ (smar A3 - ugniatany 500 razy) w porównaniu z kompozycją podstawową (smar A), która nie była poddawana wymuszeniom mechanicznym. Dla smaru A4, który podlegał wymuszeniom mechanicznym w liczbie 1000 razy zaobserwowano wzrost wartości parametru $G_{o z / 40}$ o $43,1 \%$ w stosunku do smaru A, który nie był poddany wymuszeniom mechanicznym, dla smaru A5, który podlegał wymuszeniom mechanicznym w liczbie 3000 powtórzeń, wzrost wartości wyżej wymienionego parametru wyniósł $24,7 \%$ w stosunku do kompozycji podstawowej, natomiast dla smaru A6, który był poddany wymuszeniom mechanicznym w liczbie 5000 powtórzeń, wzrost wartości parametru $G_{o z / 40}$ wyniósł 13,1\% w stosunku do kompozycji podstawowej. Dla kompozycji A7, która podlegała wymuszeniom mechanicznym w liczbie 10000 powtórzeń, zaobserwowano spadek wartości parametru $G_{o z / 40}$ o $2,9 \%$ w stosunku do kompozycji podstawowej (rysunek 1).

Kryteria jakości środków smarowych, szczególnie dla przemysłu spożywczego, są ustalane indywidualnie przez producentów maszyn. W wyniku przeprowadzonej analizy rynku można stwierdzić, że kompozycje smarowe, które charakteryzują się wartością parametru $G_{o z / 40}>600 \mathrm{~N} / \mathrm{mm}^{2}$, mają bardzo dobre właściwości przeciwzużyciowe, te - których graniczne obciążenie zużycia mieści się w przedziale $400 \div 600 \mathrm{~N} / \mathrm{mm}^{2}$ 
zapewniają skuteczną ochronę przeciwzużyciową. Natomiast w przypadku, gdy $G_{o z / 40}<400 \mathrm{~N} / \mathrm{mm}^{2}$, mówimy o niedostatecznych właściwościach przeciwzużyciowych.

Uzyskane wartości właściwości przeciwzużyciowych sprawiają, że badane kompozycje smarowe są skutecznymi produktami smarnymi w warunkach stałego obciążenia węzła tarcia.

Dla badanych smarów plastycznych poddanych wymuszeniom mechanicznym wyznaczono obciążenie zespawania $P_{z}$ oraz graniczne obciążenie zatarcia $P_{o z}$. Uzyskane rezultaty badań tych parametrów przedstawiono na rysunku 2.

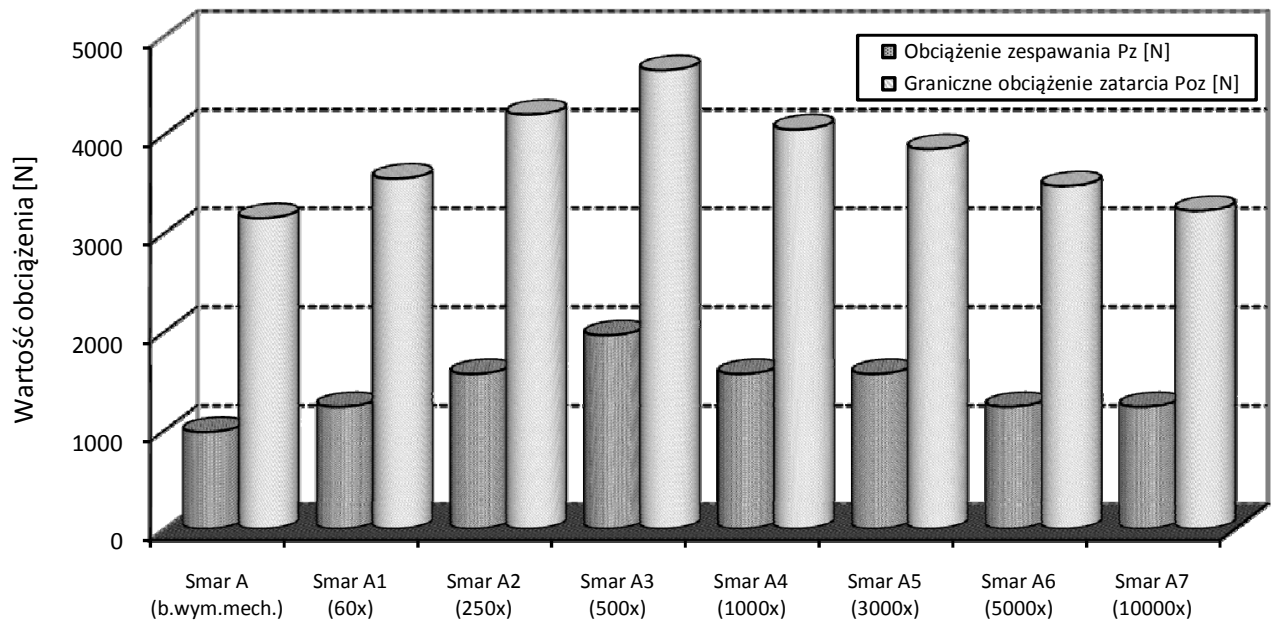

Rys. 2. Wpływ wymuszeń mechanicznych na zmianę obciążenia zespawania i granicznego obciążenia zatarcia badanych smarów plastycznych podstawowej (smar A) zaobserwowano dla kompozycji A3 (poddanej wymuszeniom mechanicznym w liczbie 500 powtórzeń). W tym przypadku zauważono wzrost wartości $P_{z}$ o $100 \%$ w porównaniu z kompozycją podstawową. Zastosowanie wymuszeń mechanicznych w zakresie $60 \div 10000$ powtórzeń poprawia właściwości przeciwzatarciowe badanych kompozycji smarowych w stopniu zadowalającym, ale najskuteczniejsze działanie przeciwzatarciowe reprezentuje kompozycja smarowa, która była poddana wymuszeniom mechanicznym w liczbie 500 powtórzeń.

Graniczne obciążenie zatarcia pozwala określić poziom właściwości przeciwzatarciowych badanych smarów plastycznych. Najkorzystniejszymi właściwościami przeciwzatarciowymi charakteryzuje się smar A3, który był poddany wymuszeniom mechanicznym w liczbie 500 powtórzeń, natomiast kompozycja A, która nie podlegała wymuszeniom mechanicznym, reprezentuje najsłabsze właściwości przeciwzatarciowe wyrażone poprzez parametr $P_{o z}$. W kompozycjach smarowych poddanych badaniom zaobserwowano wzrost wartości parametru $P_{o z}$ o: $12,7 \%$ dla smaru A1 - ugniatanego 60-krotnie; 33,3\%
Ocena właściwości przeciwzatarciowych przy skokowo narastającym obciążeniu węzła tarcia dla badanych kompozycji smarowych wykazała korzystny wpływ wymuszeń mechanicznych na trwałość filmu smarowego (rysunek 2). Najkorzystniejszymi właściwościami przeciwzatarciowymi charakteryzuje się smar A3 (ugniatany 500 razy). Dla kompozycji A1 (poddanej wymuszeniom mechanicznym w liczbie 60 powtórzeń), A6 (podlegającej wymuszeniom mechanicznym w liczbie 5000 powtórzeń) oraz A7 (poddanej wymuszeniom mechanicznym w liczbie 10000 powtórzeń) zaobserwowano wzrost wartości $P_{z}$ o $26 \%$ w porównaniu z kompozycją podstawową (smar A), która nie podlegała wymuszeniom mechanicznym. Natomiast kompozycje: A2 (poddana wymuszeniom mechanicznym w liczbie 250 powtórzeń), A4 (podlegająca wymuszeniom mechanicznym w liczbie 1000 powtórzeń) oraz A5 (poddana wymuszeniom mechanicznym w liczbie 3000 powtórzeń) wykazywały się bardzo korzystnymi zmianami właściwości przeciwzatarciowych. W każdym przypadku zaobserwowano wzrost wartości parametru $P_{z}$ o $60 \%$ w stosunku do kompozycji nie podlegającej wymuszeniom mechanicznym. Jednak największy wzrost wartości parametru $P_{z}$ w stosunku do kompozycji dla smaru A2 - ugniatanego 250 razy; 47,6\% dla smaru A3 - ugniatanego 500-krotnie; 28,6\% dla smaru A4 - ugniatanego 1000 razy; 22,2\% dla smaru A5 - ugniatanego 3000 razy; 10,3\% dla kompozycji A6 - ugniatanej 5000-krotnie oraz 2,4\% dla kompozycji A7 - ugniatanej 10000 razy w porównaniu z kompozycją podstawową (smar A), która nie podlegała procesowi mechanicznego ugniatania. Kompozycje smarowe poddawane wymuszeniom mechanicznym wykazywały korzystne zmiany właściwości przeciwzatarciowych w stosunku do kompozycji podstawowej, która nie podlegała wymuszeniom mechanicznym (rysunek 2). Najskuteczniejsze działanie środka smarowego po przerwaniu filmu smarowego zapewnia zastosowanie kompozycji poddanej wymuszeniom mechanicznym w liczbie 500 powtórzeń, co skutkuje uzyskaniem smaru o największej wartości $P_{o z}$, nie powodując jednocześnie zniszczenia jego struktury. Wartości granicznego obciążenia zatarcia dla kompozycji, które poddano wymuszeniom mechanicznym, mieszczą się w granicach $3150 \div 4650 \mathrm{~N}$, co może świadczyć o tym, że różnice w składzie smarów odgrywają istotną rolę jedynie w warunkach umiarkowanych obciążeń. W trakcie procesu zacierania wzrastające ciśnienie $\mathrm{w}$ strefie tarcia powoduje, że na 
współpracujących powierzchniach nie ma już filmu smarnego. Substancje mogące wejść $\mathrm{w}$ reakcję z materiałem pary ciernej są w stanie zapewnić działanie ochronne przed unieruchomieniem węzła tarcia. Efektem tego jest ograniczenie możliwości powstawania sczepów adhezyjnych.

Dla wybranych kompozycji smarowych poddanych wymuszeniom mechanicznym wyznaczono właściwości przeciwzatarciowe w warunkach liniowo wzrastającego obciążenia, charakteryzowane obciążeniem zacierającym $P_{t}$. Uzyskane rezultaty badań tego parametru przedstawiono na rysunku 3 .

Obciążenie zacierające określa poziom właściwości przeciwzatarciowych badanych smarów w warunkach liniowo o 39,$4 ; 27,3 ; 16,7$ oraz 7,6\% w stosunku do kompozycji, której nie poddano wymuszeniom mechanicznym. Natomiast w kompozycjach podlegających wymuszeniom w liczbie 60 i 250 powtórzeń zaobserwowano wzrost wartości parametru $P_{o z}$ o 13,6 i $21,2 \%$. Kompozycje smarowe poddawane wymuszeniom mechanicznym wykazywały się niezwykle korzystnymi zmianami właściwości przeciwzatarciowych w stosunku do kompozycji podstawowej, która nie podlegała wymuszeniom mechanicznym (rysunek 3). Najwyższą trwałość filmu smarowego zapewnia zastosowanie kompozycji poddanej 500-krotnemu ugniataniu, co powoduje uzyskanie smaru o największej wartości $P_{t}$. Można zatem zakładać, że skuteczność przeciwdziałania zacieraniu będzie zależeć od stabilności struktury warstwy granicznej tworzonej przez zastosowane składniki smaru plastycznego. Wymuszenia mechaniczne sprawiają, że poszczególne cząsteczki oleju i zagęszczacza w filmie smarowym są ściślej upakowane, co wpływa na zwiększenie ich wzajemnych oddziaływań, a więc wzrasta odporność filmu smarowego do przenoszenia większych obciążeń.

Miarą właściwości przeciwzatarciowych badanych smarów plastycznych poddanych wymuszeniom mechanicznym w warunkach zacierania jest graniczny nacisk zatarcia $p_{o z}$. Uzyskane wyniki badania tego parametru przedstawio- wzrastającego obciążenia. Właściwości charakteryzowane przez parametr $P_{t}$ określają zdolność filmu smarnego do przenoszenia obciążeń. W zależności od wielkości wymuszeń mechanicznych, którym poddane były badane kompozycje smarowe, wartość obciążenia zacierającego ulegała zmianom. Najkorzystniejszymi właściwościami przeciwzatarciowymi w warunkach liniowo wzrastającego obciążenia charakteryzuje się kompozycja poddana wymuszeniom mechanicznym w liczbie 500 powtórzeń (smar A3). Zaobserwowano wzrost wartości $P_{t}$ o $51,5 \%$ w porównaniu ze smarem, który nie podlegał wymuszeniom mechanicznym (smar A). Słabszymi właściwościami w porównaniu z kompozycją A3 charakteryzują się smary, które zostały poddane większym (1000, 3000, 5000 czy 10 000-krotnemu ugniataniu), jak również mniejszym wymuszeniom (60 i 250-krotnemu ugniataniu). Wartość $P_{t}$ wzrasta odpowiednio no na rysunku 4.

Właściwości przeciwzatarciowe badanych kompozycji smarowych w warunkach zacierania zależą od wielkości wymuszeń mechanicznych, które znacząco wpływają na charakterystykę smarną wytworzonych kompozycji.

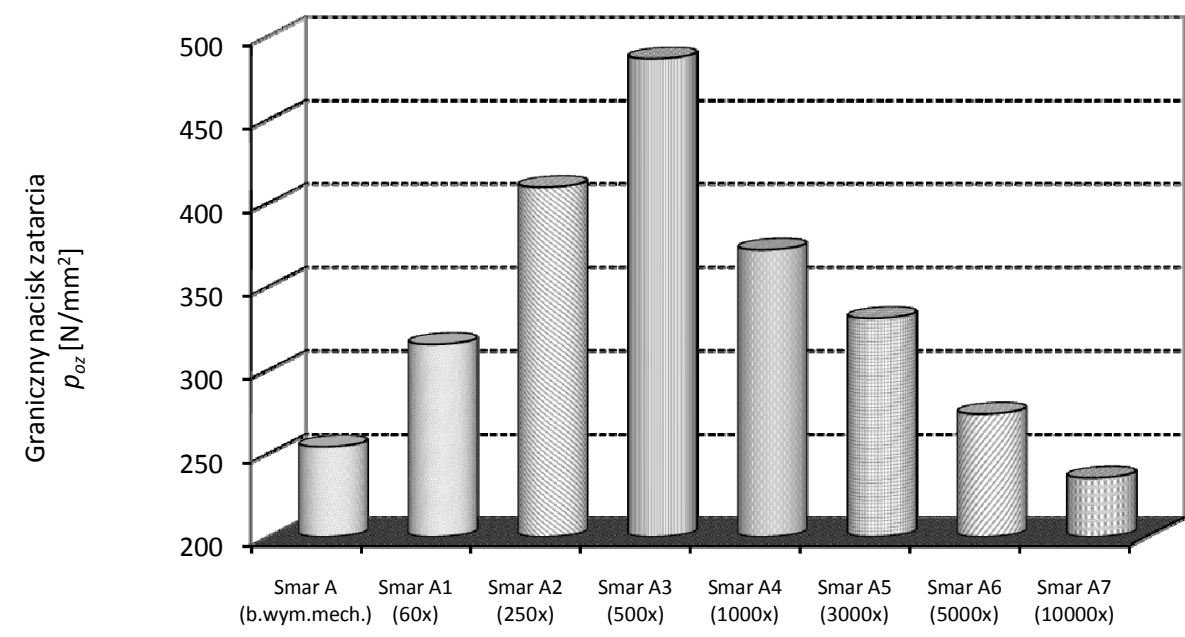

Rys. 4. Wpływ wymuszeń mechanicznych na zmianę granicznego nacisku zatarcia badanych smarów plastycznych 
Najkorzystniejszymi właściwościami przeciwzatarciowymi w warunkach zacierania odznacza się smar poddany wymuszeniom mechanicznym w liczbie 500 powtórzeń (smar A3). W tym przypadku zaobserwowano wzrost wartości $p_{o z}$ o 91,5\% w porównaniu z kompozycją, która nie podlegała wymuszeniom mechanicznym (smar A). Słabszymi właściwościami w porównaniu ze smarem A3 charakteryzują się smary, które zostały poddawane większym wymuszeniom (1000, 3000, 5000-krotnemu ugniataniu). Wartość $p_{o z}$ wzrasta odpowiednio o 46,$4 ; 30,3 ; 7,8 \%$ w porównaniu z kompozycją, która nie podlegała wymuszeniom mechanicznym. Natomiast dla kompozycji smarowej poddanej wymuszeniom mechanicznym w liczbie 10000 powtórzeń zaobserwowano spadek wartości parametru $p_{o z}$ o 7,3\% w stosunku do kompozycji podstawowej (smar A). W kompozycjach smarowych podlegających wymuszeniom w liczbie 60 i 250 powtórzeń zauważono wzrost wartości parametru $p_{o z}$ odpowiednio o 24,1 i $61,2 \% \mathrm{w}$ stosunku do kompozycji smarowej nie poddawanej wymuszeniom mechanicznym. Kompozycje smarowe podlegające coraz większym wymuszeniom mechanicznym nie wykazywały tak korzystnych zmian właściwości przeciwzatarciowych jak kompozycja poddana wymuszeniom w liczbie 500 powtórzeń. Podwyższały one jednak wartość omawianego parametru $\left(p_{o z}\right)$ - poza kompozycją A7, która podlegała największym wymuszeniom mechanicznym, tj. 10 000-krotnemu ugniataniu w stosunku do kompozycji, której nie poddano wymuszeniom mechanicznym (rysunek 4). Wyznaczone wartości granicznego nacisku zatarcia wykazały, że wymuszenia mechaniczne korzystnie wpływają na poprawę właściwości przeciwzatarciowych kompozycji smarowych zastosowanych w eksperymencie tylko do pewnej granicy, później następuje powolne osłabienie odporności warstwy wierzchniej na zacieranie. Poddanie badanych smarów plastycznych wymuszeniom mechanicznym w liczbie $60 \div 5000$ powtórzeń poprawia właściwości przeciwzatarciowe w stosunku do kompozycji smarowej, która nie podlegała wymuszeniom mechanicznym. Parametr $p_{o z}$ dostarcza informacji o ciśnieniu panującym w strefie tarcia w momencie zatarcia. Na podstawie otrzymanych wyników można stwierdzić, że wymuszenia mechaniczne nie wpływają na tworzenie wysokoodpornych na zacieranie warstw wierzchnich. Wyższy parametr $p_{o z}$ w przypadku smaru A3 poddanego wymuszeniom mechanicznym w liczbie 500 powtórzeń wskazuje, że charakter tworzonego filmu sprzyja znacznemu zmniejszeniu zużycia.

W celu potwierdzenia otrzymanych wyników należy wykonać analizę warstwy wierzchniej badanych smarów plastycznych (XPS, EDS, FTIR, IR).

\section{Podsumowanie}

Na podstawie wyników przeprowadzonych badań stwierdzono, że właściwości tribologiczne badanych kompozycji smarowych uległy istotnej zmianie pod wpływem wymuszeń mechanicznych.

Badania przeprowadzono na aparacie czterokulowym przy styku skoncentrowanym. Analizowano kompozycje smarowe poddane wymuszeniom mechanicznym w liczbie $60 \div 10000$ powtórzeń. Otrzymane wyniki jednoznacznie potwierdziły pozytywny wpływ wymuszeń mechanicznych na właściwości tribologiczne badanych smarów plastycznych podczas tarcia stalowych skojarzeń (tablica 2).

Wyznaczone wartości obciążenia zespawania charakteryzującego właściwości przeciwzatarciowe przy skokowo narastającym obciążeniu węzła tarcia, a także granicznego nacisku zatarcia określającego właściwości przeciwzatarciowe w warunkach zacierania wykazały, że zastosowanie wymuszeń mechanicznych w liczbie 500 powtórzeń najskuteczniej wpływa na zmianę właściwości przeciwzatarciowych zastosowanych w eksperymencie smarów plastycznych.

Modyfikowanie smarów plastycznych poprzez zastosowanie wymuszeń mechanicznych powoduje poprawę ich właściwości smarnych do momentu osiągnięcia pewnego maksimum (500-krotne ugniatanie), większe wymusze- nia mechaniczne wywołują pogorszenie właściwości tribologicznych smarów plastycznych wytworzonych na mineralnej bazie olejowej. Wymuszenia mechaniczne w liczbie $60 \div 500$ powtórzeń skutkują utworzeniem ochronnego filmu na powierzchni, który wpływa na wzrost odporności węzła na zacieranie. W wyniku poprawy własności warstwy granicznej rozpoczęcie zacierania następuje przy większym obciążeniu węzła tarcia.

Pod wpływem wymuszeń mechanicznych (maksymalnie 500-krotne ugniatanie) następuje wzrost parametru $G_{o z}$, co wskazuje na dużą odporność na przerywanie warstwy granicznej. Świadczy to o pozytywnym wpływie niewielkich wymuszeń mechanicznych na poprawę charakterystyk tribologicznych badanych smarów plastycznych.

Zastosowanie optymalnej wielkości wymuszeń mechanicznych w badanych smarach plastycznych powoduje utworzenie na powierzchni stalowej niskotarciowej warstwy wierzchniej odpornej na wysokie obciążenia jednostkowe, co skutkuje zwiększeniem trwałości i sprawności wielu skojarzeń ślizgowych.

Zaobserwowano, że proces fizycznego ugniatania (do 500 razy) skutecznie modyfikuje właściwości przeciwzatarciowe i przeciwzużyciowe mineralnych smarów krzemionkowych. 
Tablica 2. Właściwości tribologiczne badanych kompozycji smarowych

\begin{tabular}{|c|c|c|c|c|c|}
\hline $\begin{array}{c}\text { Badany } \\
\text { smar }\end{array}$ & $\begin{array}{c}\text { Obciążenie } \\
\text { zespawania } P_{z} \\
{[\mathrm{~N}]}\end{array}$ & $\begin{array}{c}\text { Graniczne obciążenie } \\
\text { zużycia } G_{o z / 40} \\
{\left[\mathrm{~N} / \mathrm{mm}^{2}\right]}\end{array}$ & $\begin{array}{c}\text { Obciążenie } \\
\text { zacierające } P_{t} \\
{[\mathrm{~N}]}\end{array}$ & $\begin{array}{c}\text { Graniczne obciążenie } \\
\text { zatarcia } P_{o z} \\
{[\mathrm{~N}]}\end{array}$ & $\begin{array}{c}\text { Graniczny nacisk } \\
\text { zatarcia } p_{o z} \\
{\left[\mathrm{~N} / \mathrm{mm}^{2}\right]}\end{array}$ \\
\hline A & 981,0 & 454,55 & 1650 & 3150 & 253,89 \\
\hline A1 & 1236,0 & 530,82 & 1875 & 3550 & 315,21 \\
\hline A2 & 1569,6 & 628,03 & 2000 & 4200 & 409,29 \\
\hline A3 & 1962,0 & 726,41 & 2500 & 4650 & 486,24 \\
\hline A4 & 1569,6 & 650,66 & 2300 & 4050 & 371,81 \\
\hline A5 & 1569,6 & 566,83 & 2100 & 3850 & 330,82 \\
\hline A6 & 1236,0 & 514,11 & 1925 & 3475 & 273,58 \\
\hline A7 & 1236,0 & 441,28 & 1775 & 3225 & 235,27 \\
\hline
\end{tabular}

Prosimy cytować jako: Nafta-Gaz 2016, nr 1, s. 50-57, DOI: 10.18668/NG2016.01.07

Artykuł nadesłano do Redakcji 11.05.2015 r. Zatwierdzono do druku 23.10.2015 r.

\section{Literatura}

[1] Aerosil@: Manifacture, properties and applications. Technical Bullettin Pigments N. 11, Degussa-Huls AG, Germany.

[2] Albertini B., Passerini N., Gonzalez-Rodriguez M. L., Perissutti B., Rodriguez L.: Effect of Aerosil ${ }^{\circledR}$ on the properties of lipid controlled release microparticles. Journal of Controlled Release 2004, vol. 100, s. 233-246.

[3] Bartz W. J.: Ecotribology: environmentally acceptable tribological practices. Tribology International 2006, vol. 39, s. 728-733.

[4] Bartz W. J.: Lubricants and the environment. Tribology International 1998, vol. 31, s. 35-47.

[5] Burakowski T., Marczak R.: Eksploatacyjna warstwa wierzchnia $i$ jej badanie. Zagadnienia Eksploatacji Maszyn 1995, vol. 103, nr 3, s. 327-337.

[6] Górska K.: Właściwości smarne i przeciwzużyciowe. Część 3 Maszyny do badania zjawisk $w$ strefie tarcia. Paliwa, Oleje i Smary w Eksploatacji 1996, nr 27, s. 22-26.

[7] Górska K.: Wtaściwości smarne. Część. 2 - Maszyna czterokulowa. Paliwa, Oleje i Smary w Eksploatacji 1995, nr 19, s. 19-24.

[8] Havet L., Blouet J., Robbe Valloire F., Brasseur E., Slomka D.: Tribological characteristics of some environmentally friendly lubricants. Wear 2001, vol. 248, s. 140-146.

[9] Janecki J., Drabik J., Pawelec E., Bajer J.: Badanie wptywu biodegradowalnych baz olejowych na właściwości smaru plastycznego. Sprawozdanie z realizacji działalności statutowej. Instytut Technologii Eksploatacji. Radom 1998.

[10] Janecki J., Drabik J., Pawelec E., Bajer J.: Uruchomienie produkcji nietoksycznych środków smarowych przeznaczonych do maszyn i urządzeń przemystu spożywczego. Program celowy. Instytut Technologii Eksploatacji. Radom 1997-2000.

[11] Jonat S., Hasenzahl S., Drechsler M., Albers P., Wagner K. G., Schmidt P. C.: Investigation of compacted hydrophilic and hydrophobic colloidal silicon dioxides as glidants for pharmaceutical excipients. Powder Technology 2004, vol. 141, nr 1-2, s. 31-43.

[12] Kalin M., Vižintin J.: A comparison of the tribological behaviour of steel/steel, steel/DLC and DLC/DLC contacts when lubricated with mineral and biodegradable oils. Wear 2006, vol. 261, s. 22-31.

[13] Karta charakterystyki oleju parafinowego FINAVESTAN $A 360 B$. Materiały firmy Total, 1998.
[14] Keller U. i in.: Neue Schmier stoffe auf der Basis nachwachsender Rohstoffe: Okotoxikologische und oxidative Eigenschaften. Olenhydraulik und Pneumatik 2000, nr 4, s. 385-395.

[15] Kozdrach R.: Wplyw synergizmu dodatków zawierajacych krzem na zmiany charakterystyk tribologicznych smaru plastycznego. Nafta-Gaz 2015, nr 2, s. 110-118.

[16] Kozdrach R.: Wplyw wymuszeń mechanicznych na zmiane właściwości smarnych biodegradowalnego smaru plastycznego wytworzonego na bazie roślinnej. Nafta-Gaz 2012, nr 11, s. $868-876$.

[17] Lundberg J., Hoglund E.: A new method for determining the mechanical stability of lubricating greases. Tribology International 2000, vol. 33, s. 217-223.

[18] Morefield E.: Colloidal silicon dioxide. Handbook of Pharmaceutical Excipients 3rd edition, Arthur H. Kibbe. Washington 2000, s. 143-145.

[19] Neville A., Morina A., Haque T., Voong M.: Compatibility between tribological surfaces and lubricant additives - How friction and wear reduction can be controlled by surfach/lube synergies. Tribology International 2007, vol. 40, s. 1680-1695.

[20] Stachowiak G. W., Batchelor A. W.: Engineering tribology. Butterworth-Heinemann 2006, s. 363-417.

[21] Szczerek M., Tuszyński W.: Badania tribologiczne. Zacieranie. Wydawnictwo Instytutu Technologii Eksploatacji. Radom 2000.

\section{Akty prawne i normatywne}

[22] Norma PN-76/C-04147 Przetwory naftowe. Badanie wtasności smarnych olejów i smarów.

[23] Norma WTWT-94/MPS-025 Wojskowe Tymczasowe Wymagania Techniczne. Badanie właściwości przeciwzużyciowych materiatów pędnych i smarowych.

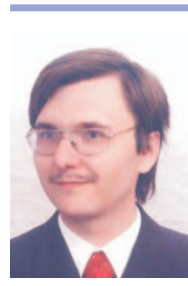

Mgr inż. Rafał KOZDRACH

Instytut Technologii Eksploatacji - Państwowy

Instytut Badawczy

ul. Pułaskiego 6/10

26-600 Radom

E-mail: rafal.kozdrach@itee.radom.pl 